\title{
Data report: Quaternary dinoflagellate cyst and pollen census counts from IODP Hole U1352B, Canterbury Basin, New Zealand ${ }^{1}$
}

\author{
Joseph Graham Prebble, ${ }^{2}$ Erica M. Crouch, ${ }^{2}$ and Giuseppe Cortese ${ }^{2}$
}

\section{Chapter contents}

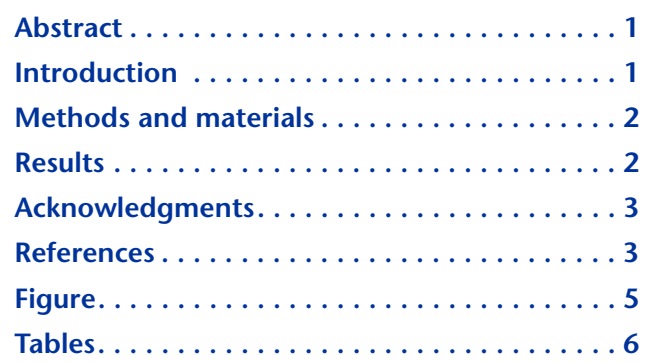

1 Prebble, J.G., Crouch, E.M., and Cortese, G., 2014. Data report: Quaternary dinoflagellate cyst and pollen census counts from IODP Hole U1352B, Canterbury Basin, New Zealand. In Fulthorpe, C.S., Hoyanagi, K., Blum, P., and the Expedition 317 Scientists, Proc. IODP, 317: Tokyo (Integrated Ocean Drilling Program Management International, Inc.).

doi:10.2204/iodp.proc.317.207.2014

${ }^{2}$ GNS Science, PO Box 30368, Lower Hutt 5040, New Zealand.

Correspondence author: j.prebble@gns.cri.nz

\section{Abstract}

Pollen, spore, and dinoflagellate cyst census counts are reported from Hole U1352B, part of Integrated Ocean Drilling Program Expedition 317 to the Canterbury Basin, New Zealand. Fifty one samples were processed for palynology between 91.1 and $181.5 \mathrm{~m}$ composite depth. Based on the shipboard biostratigraphy, the samples described here include sediment deposited during marine isotope Stages 12-10. Preservation of dinoflagellate cysts and pollen was generally good, although palynomorphs were frequently obscured by the presence of abundant terrestrial organic matter (cuticle and wood fragments) that was observed in all slides. Dinoflagellate cyst assemblages were dominated by the heterotrophic genus Brigantedinium, which made up, on average, $78 \%$ of the assemblage (range $=36 \%-98 \%$ ). Alternation of two broad pollen associations was observed. Pollen assemblages dominated by Poaceae, Halocarpus, Phyllocladus, and Caryophyllaceae/Chenopodiaceae, interpreted to represent an alpine or cooler climate vegetation, alternated with a pollen assemblage dominated by Fuscospora fusca and Prumnopitys/Podocarpus, reflecting warmer interglacial conditions.

\section{Introduction}

The purpose of this pilot study was to assess the suitability of marine and terrestrial palynomorph assemblages from Hole U1352B for combined paleoenvironmental reconstructions of both the eastern South Island terrestrial vegetation and the nearby surface ocean. Previous studies of marine and terrestrial palynomorphs from Deep Sea Drilling Project Site 594, farther east and offshore of the present site, revealed glacial-interglacial changes in pollen assemblages over the last 350 k.y. (Heusser and Van der Geer, 1994) and dinoflagellates cyst assemblages back to $125 \mathrm{ka}$ (Marret et al., 2001). Records from Site U1352 were investigated to add to this information for two reasons. The site is closer to land, with a more constrained pollen source area and is under a different surface-water mass than Site 594, which is overlain by a narrow tongue of partly subtropical water (the Southland Front) that flows around the eastern margin of South Island (Sutton, 2003)

Coring in Hole U1352B recovered $613 \mathrm{~m}$ of sediment from the offshore Canterbury Basin, eastern South Island, New Zealand, in November 2009 (see the "Site U1352" chapter [Expedition 317 
Scientists, 2011]). This data report documents the presence of dinoflagellate cysts and pollen and spores from 51 samples, which were collected between 91.1 and $181.5 \mathrm{~m}$ composite depth (mcd). Based on the shipboard biostratigraphy (see the "Site U1352" chapter [Expedition 317 Scientists, 2011]), the samples described here include sediment deposited during marine isotope Stages 12-10. The Stage 11 interval was targeted because it had a prolonged period of stable interglacial climate and a similar orbital solution to the present and thus has some similarity to the Holocene (e.g., Siegenthaler et al., 2005; Tzedakis et al., 2009). Additional high-resolution age control required for detailed study is not yet available for this core. Should this become available through future postcruise research, more detailed interpretation and expansion of the present palynomorph data set may be warranted.

\section{Methods and materials}

Fifty one samples were analyzed for palynology between 91.1 and 181.5 mcd. Samples were processed as described in Crouch et al. (2010) and Prebble et al. (2013) at the GNS Science Palynology Laboratory, Lower Hutt, New Zealand. This laboratory has positive filtered air pressure to minimize contamination during processing. Samples of $5 \mathrm{~cm}^{3}$ were oven dried at $50^{\circ} \mathrm{C}$ for $24 \mathrm{~h}$ and then weighed. A Lycopodium tablet (batch Number 938934) was added to obtain absolute abundance counts (e.g., Mertens et al., 2009). Cold $10 \% \mathrm{HCl}$ was added to the dried sample to remove carbonates, followed by $24 \mathrm{~h}$ in cold $52 \%$ $\mathrm{HF}$ and a second $10 \% \mathrm{HCl}$ wash. Samples were placed in an ultrasonic bath for up to $1 \mathrm{~min}$, sieved through $6 \mu \mathrm{m}$ mesh to remove small particulate material, and then mounted on glass slides in glycerine jelly. All slides and residues are held in the paleontology collections at GNS Science.

All counts were completed on a light microscope at $500 \times$ magnification. For most samples two entire slides were examined. For dinoflagellate cysts, taxonomy and nomenclature followed Zonneveld (1997), Rochon et al. (1999), Marret and Zonneveld (2003), Radi et al. (2013), and references therein, with identification to species level where possible. Broken cysts were counted per 0.25 of a specimen. For pollen and spores, identification was mostly to a generic level and followed Pocknall (1981a, 1981b, 1981c), Large and Braggins (1991), and Moar (1993). Some taxa, including the frost-intolerant Ascarina lucida, were grouped into an "undifferentiated angiosperms" category. Division within the podocarps followed Heusser and Van der Geer (1994), with Dacrydium cupressinum, Dacrycarpus dacrydioides,
Halocarpus sp., and Phyllocladus spp. differentiated, whereas Prumnopitys spp. and Podocarpus spp. were grouped. Fuscospora fusca pollen, Lophozonia menzeisii, and Trisyngyne brassii were separated. Cyathea spp. and other trilete and monolete spores were counted outside of the dry land sum. Notwithstanding the exceptions outlined above, nomenclature followed Moar et al. (2011).

\section{Results}

Preservation of dinoflagellate cysts and pollen was generally good, although palynomorphs were frequently obscured by the abundant terrestrial organic matter (cuticle and wood fragments) observed in all slides. No oxidation was undertaken during processing in order to reduce loss of sensitive dinoflagellate cysts, but oxidation and other steps to concentrate the pollen fraction are advised for future pollen and spore studies from this interval.

\section{Dinoflagellate cysts}

On average, 203 specimens were counted per sample (range $=7-374$ specimens). Twenty five taxa or groups of dinoflagellate cysts were identified. Count data are included in Table T1, and relative abundance of selected taxa shown in Figure F1.

Assemblages were dominated by Brigantedinium spp., which made up $78 \%$ of the assemblage on average (range $=36 \%-98 \%$ ). Other common taxa occurring throughout the sequence were Selenopemphix quanta and Selenopemphix nephroides (Selenopemphix undulata Verleye and Louwye was not differentiated from $S$. nephroides). Bitectatodinium tepikiense, ?Islandium minutum, and Quinquecuspis concreta were common in a few samples.

Gonyaulacoid cysts were considerably rarer than peridinoid cysts. The most frequently occurring form was Operculodinium centrocarpum sensu Wall and Dale, which never exceeded $10 \%$ of the assemblage. These proportions are similar to those recorded in surface sediment from the area (Crouch et al., 2010; Prebble et al., 2013).

The dinoflagellate cyst assemblages are likely too uniform to allow detailed paleoenvironmental reconstruction, although this uniformity may itself demonstrate a degree of consistency of the surfacewater masses in the area on glacial-interglacial timescales.

\section{Pollen and spores}

On average, 124 pollen and spore grains were counted per sample (range $=2-450$ specimens). Sixty seven taxa or groups of pollen and spores were iden- 
tified. Count data are included in Table $\mathrm{T} 2$, and relative abundance of selected taxa is shown in Figure F1.

Spores, dominated by Cyathea, composed on average $15 \%$ (range $=3 \%-35 \%$ ) of the pollen and spore assemblages. Gymnosperm pollen was dominated by Prumnopitys/Podocarpus species and Halocarpus. The most common angiosperm pollen was from Poaceae, Asteraceae, and F. fusca.

An alternation of two broad pollen associations was observed. Pollen of Poaceae, Halocarpus, Phyllocladus, and Caryophyllaceae/Chenopodiaceae, interpreted to represent an alpine or cooler climate vegetation, alternates with a pollen assemblage dominated by $F$. fusca and Prumnopitys/Podocarpus, reflecting warmer/ interglacial conditions.

\section{Acknowledgments}

This research used samples and data provided by the Integrated Ocean Drilling Program (IODP). Sample processing was funded by the GNS Global Change through Time (GCT) Programme supported by the New Zealand Government. J. Prebble was supported by a New Zealand Government-funded graduate scholarship. Samples were processed at GNS Science by Sonja Fry and Roger Tremain. We also thank the anonymous reviewer for his or her helpful suggestions.

\section{References}

Crouch, E.M., Mildenhall, D.C., and Neil, H.L., 2010. Distribution of organic-walled marine and terrestrial palynomorphs in surface sediments, offshore eastern New Zealand. Mar. Geol., 270(1-4):235-256. doi:10.1016/ j.margeo.2009.11.004

Expedition 317 Scientists, 2011. Site U1352. In Fulthorpe, C.S., Hoyanagi, K., Blum, P., and the Expedition 317 Scientists, Proc. IODP, 317: Tokyo (Integrated Ocean Drilling Program Management International, Inc.). doi:10.2204/iodp.proc.317.104.2011

Heusser, L.E., and Van de Geer, G., 1994. Direct correlation of terrestrial and marine paleoclimate records from four glacial-interglacial cycles-DSDP Site 594, Southwest Pacific. Quat. Sci. Rev., 13(3):273-282. doi:10.1016/ 0277-3791(94)90030-2

Large, M.F., and Braggins, J.E., 1991. Spore Atlas of New Zealand Ferns and Fern Allies: Wellington, New Zealand (SIR Publishers).

Marret, F., de Vernal, A., Benderra, F., and Harland, R., 2001. Late Quaternary sea-surface conditions at DSDP Hole 594 in the southwest Pacific Ocean based on dinoflagellate cyst assemblages. J. Quat. Sci., 16(7):739-751. doi:10.1002/jqs.648
Marret, F., and Zonneveld, K.A.F., 2003. Atlas of modern organic-walled dinoflagellate cyst distribution. Rev. Palaeobot. Palynol., 125(1-2):1-200. doi:10.1016/S00346667(02)00229-4

Mertens, K.N., Verhoeven, K., Verleye, T., Louwye, S., Amorim, A., Ribeiro, S., Deaf, A.S., Harding, I.C., De Schepper, S., González, C., Kodrans-Nsiah, M., De Vernal, A., Henry, M., Radi, T., Dybkjaer, K., Poulsen, N.E., Feist-Burkhardt, S., Chitolie, J., Heilmann-Clausen, C., Londeix, L., Turon, J.-L., Marret, F., Matthiessen, J., McCarthy, F.M.G., Prasad, V., Pospelova, V., Kyffin Hughes, J.E., Riding, J.B., Rochon, A., Sangiorgi, F., Welters, N., Sinclair, N., Thun, C., Soliman, A., Van Nieuwenhove, N., Vink, A., and Young, M., 2009.

Determining the absolute abundance of dinoflagellate cysts in recent marine sediments: the Lycopodium marker-grain method put to the test. Rev. Palaeobot. Palynol., 157(3-4):238-252. doi:10.1016/ j.revpalbo.2009.05.004

Moar, N.T., 1993. Pollen Grains of New Zealand Dicotyledonous Plants: Christchurch, New Zealand (Manaaki Whenua Press).

Moar, N.T., Wilmshurst, J.M., and McGlone, M.S., 2011. Standardizing names applied to pollen and spores in New Zealand Quaternary palynology. N. Z. J. Bot., 49(2):201-229.

Prebble, J.G., Crouch, E.M., Carter, L., Cortese, G., Bostock, H., and Neil, H., 2013. An expanded modern dinoflagellate cyst dataset for the Southwest Pacific and Southern Hemisphere with environmental associations. Mar. Micropaleontol., 101:33-48. doi:10.1016/j.marmicro.2013.04.004

Pocknall, D.T., 1981a. Pollen morphology of Phyllocladus L. C. et A. Rich. N. Z. J. Bot., 19(3):259-266. doi:10.1080/ 0028825X.1981.10426378

Pocknall, D.T., 1981b. Pollen morphology of the New Zealand species of Dacrydium Selander, Podocarpus L'Heritier, and Dacrycarpus Endlicher (Podocarpaceae). N. Z. J. Bot., 19(1):67-95. doi:10.1080/ 0028825X.1981.10425191

Pocknall, D.T., 1981c. Pollen morphology of the New Zealand species of Libocedrus Endlicher (Cupressaceae) and Agathis Salisbury (Araucariaceae). N. Z. J. Bot., 19(3):267-272. doi:10.1080/ 0028825X.1981.10426379

Radi, T., Bonnet, S., Cormier, M.-A., de Vernal, A., Durantou, L., Faubert, É., Head, M.J., Henry, M., Pospelova, V., Rochon, A., and Van Nieuwenhove, N., 2013. Operational taxonomy and (paleo-)autecology of round, brown, spiny dinoflagellate cysts from the Quaternary of high northern latitudes. Mar. Micropaleontol., 98:4157. doi:10.1016/j.marmicro.2012.11.001

Rochon, A., de Vernal, A., Turon, J.L., Mathiessen, J., and Head, M.J., 1999. Distribution of Recent dinoflagellate cysts in surface sediments from the North Atlantic Ocean and adjacent seas in relation to sea-surface parameters. Am. Assoc. Stratigr. Palynol. Contrib. Ser., 35.

Siegenthaler, U., Stocker, T.F., Monnin, E., Lüthi, D., Schwander, J., Stauffer, B., Raynaud, D., Barnola, J.-M., Fischer, H., Masson-Delmotte, V., and Jouzel, J., 2005. 
Stable carbon cycle-climate relationship during the late Pleistocene. Science, 310(5752):1313-1317.

doi:10.1126/science.1120130

Sutton, P.J.H., 2003. The Southland Current: a subantarctic current. N. Z. J. Mar. Freshwater Res., 37(3):645-652. doi:10.1080/00288330.2003.9517195

Tzedakis, P.C., Raynaud, D., McManus, J.F., Berger, A., Brovkin, V., and Kiefer, T., 2009. Interglacial diversity. Nat. Geosci., 2(11):751-755. doi:10.1038/ngeo660
Zonneveld, K.A.F., 1997. New species of organic walled dinoflagellate cysts from modern sediments of the Arabian Sea (Indian Ocean). Rev. Palaeobot. Palynol., 97(34):319-337. doi:10.1016/S0034-6667(97)00002-X

Initial receipt: 15 July 2013

Acceptance: 20 March 2014

Publication: 14 May 2014

MS 317-207 


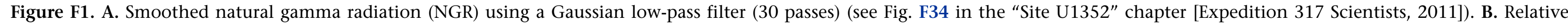

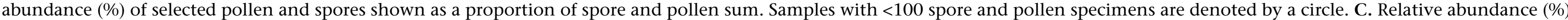

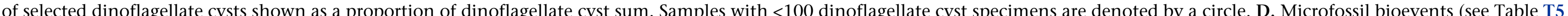

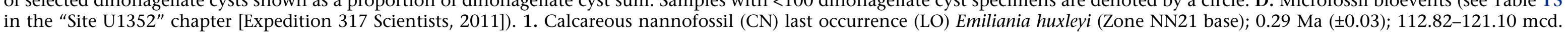

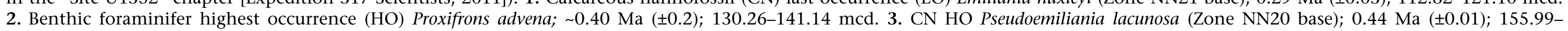

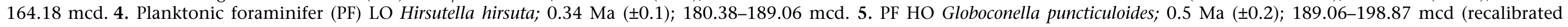
at Site U1352).

A

NGR
(cps)

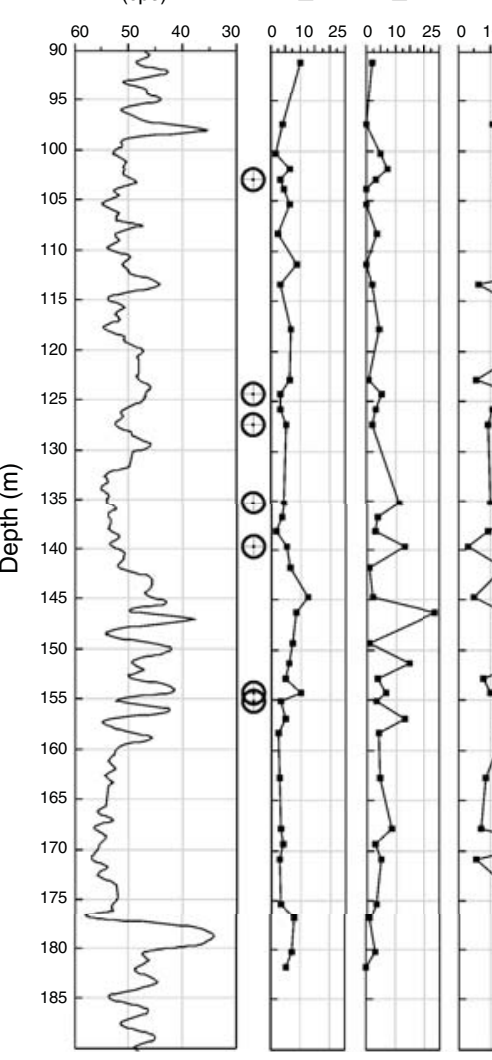

B

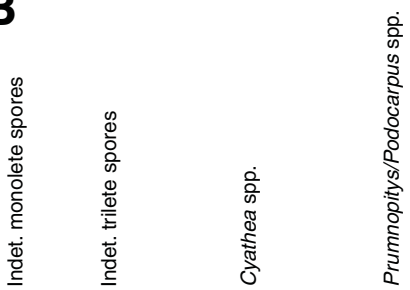

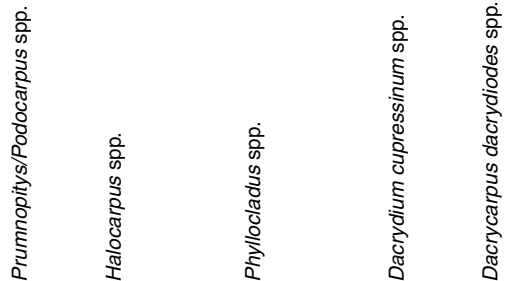

密
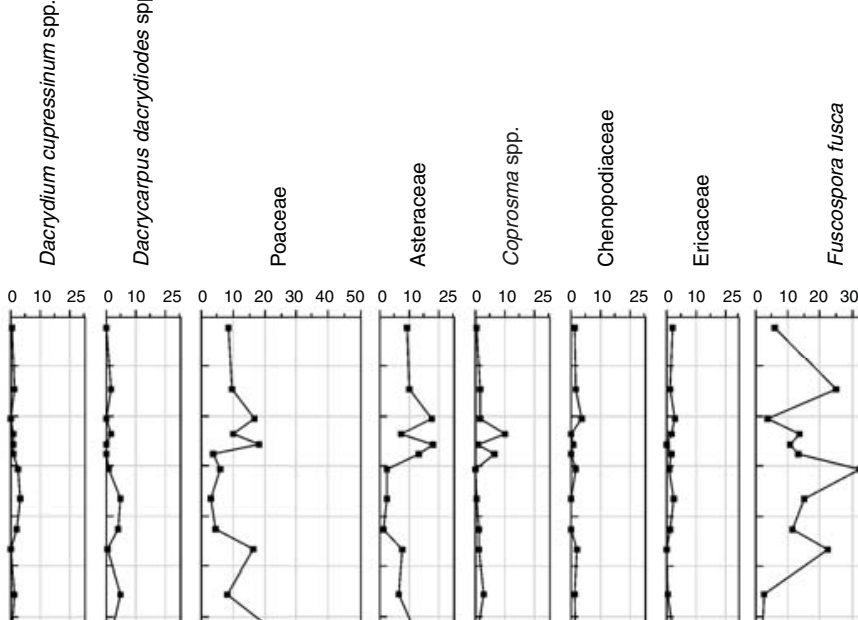
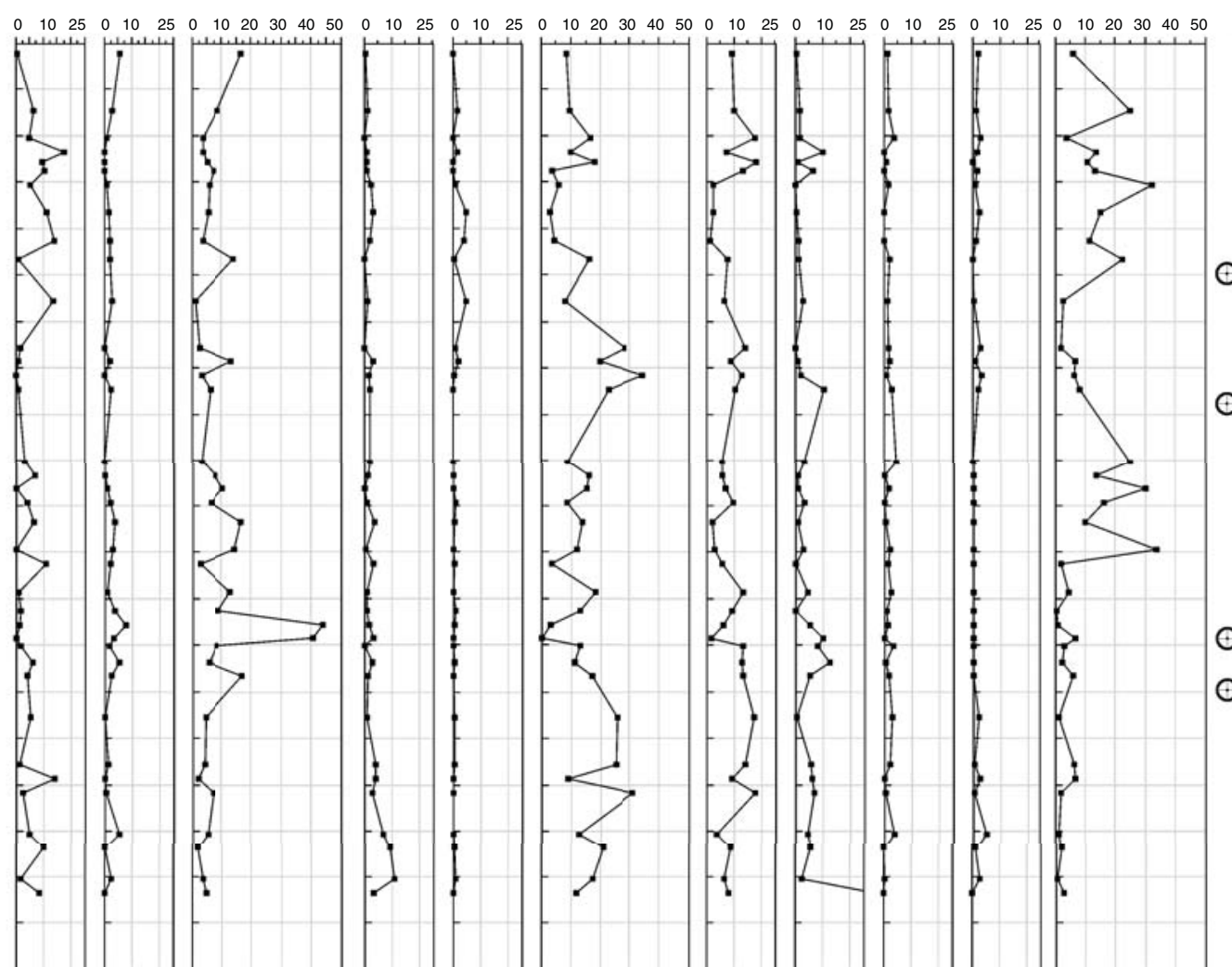

C

C

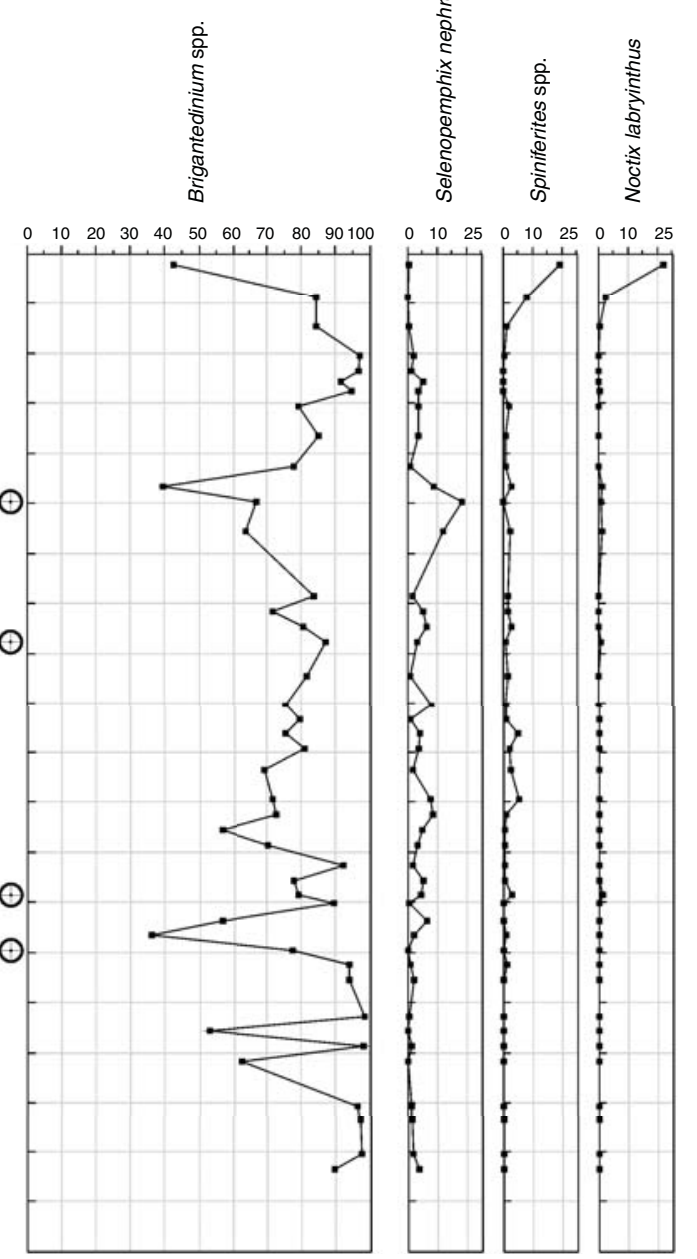

D 


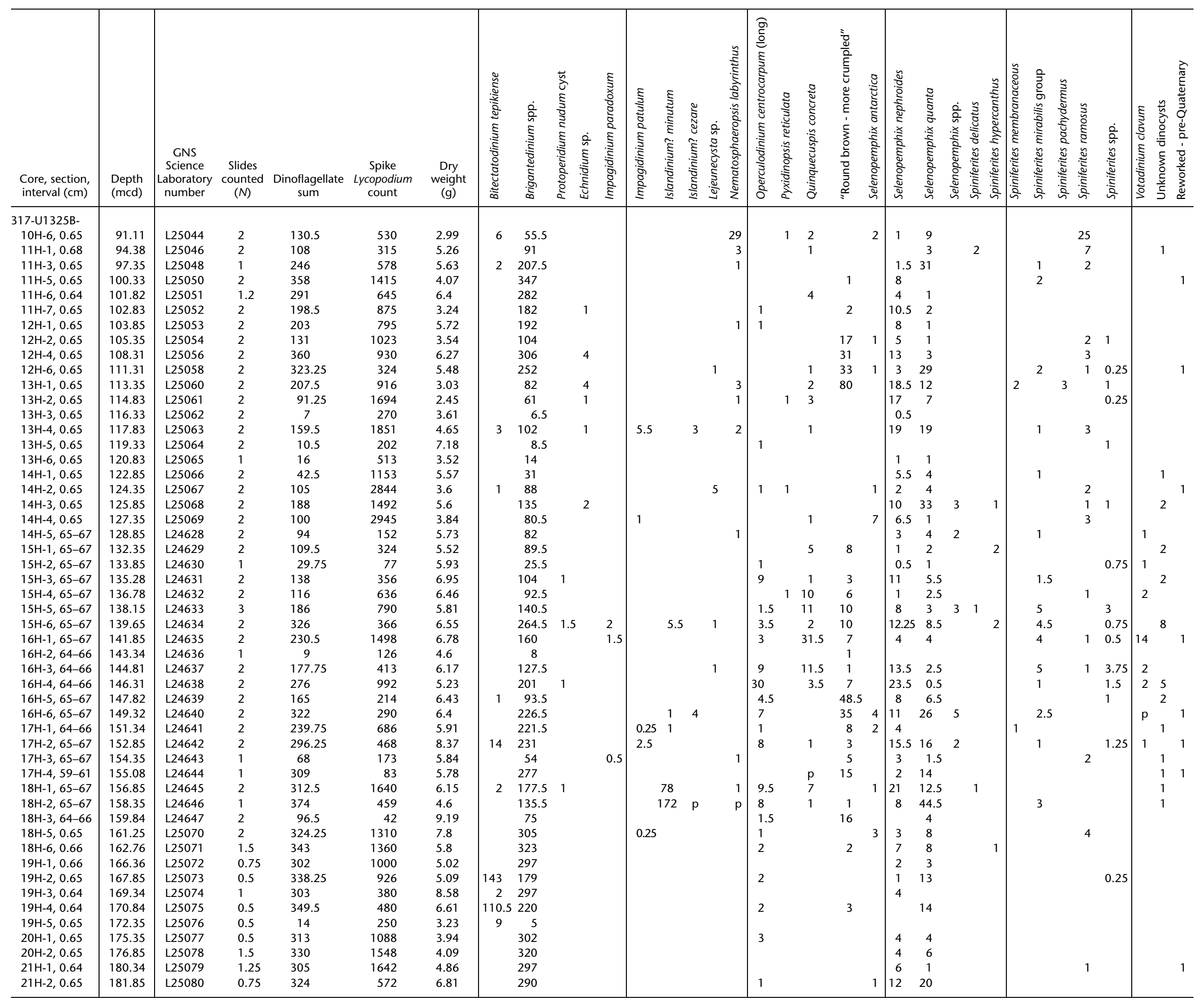




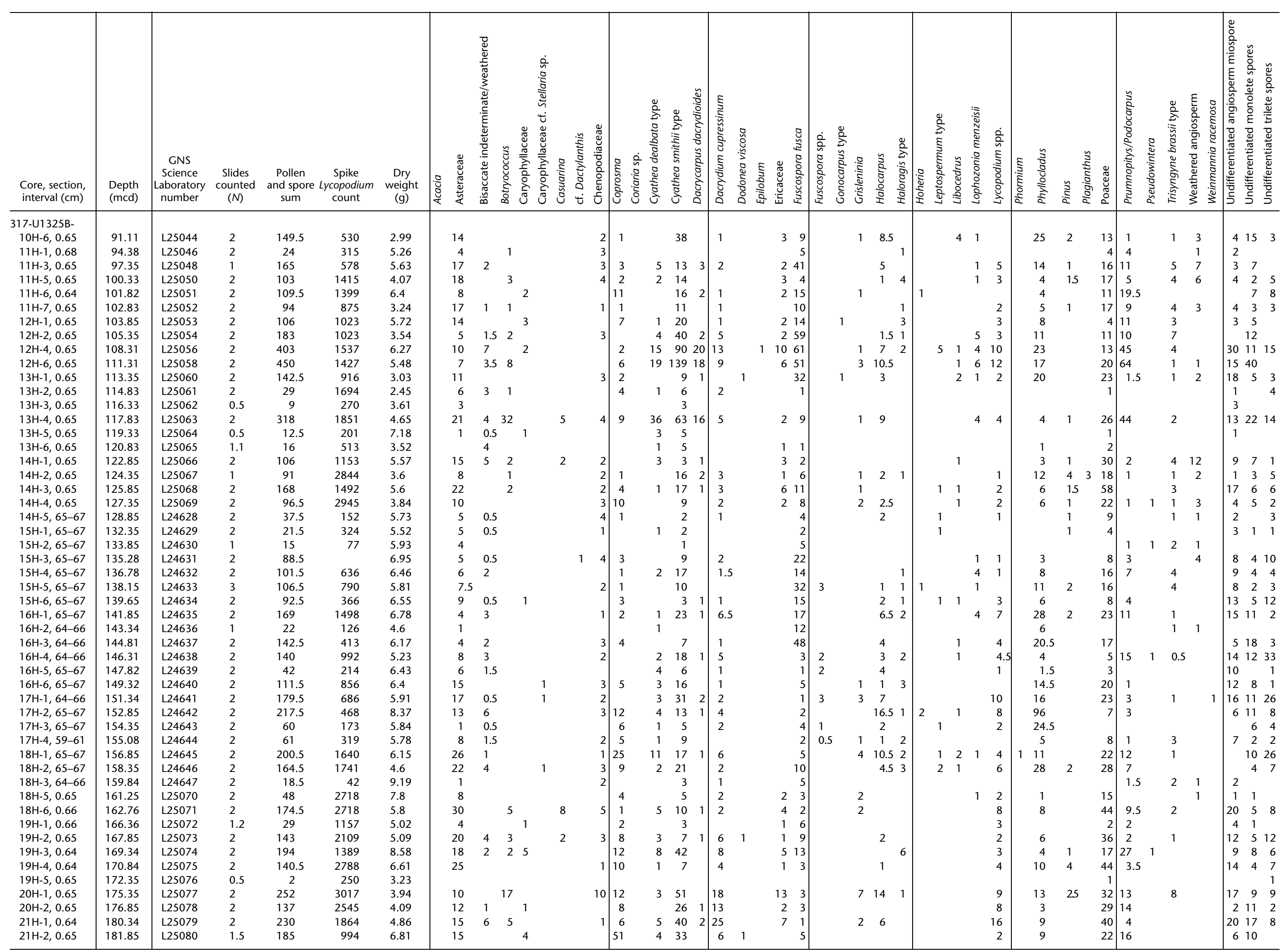

